\title{
Survey of Gymnophalloides seoi Metacercariae in Natural and Cultured Oysters from Several Western Coastal Areas, Korea
}

\author{
Taehee Chang', Bong-Kwang Jung,", Hyemi Song', Jaeeun Cho', Sooji Hong', Keon-Hoon Lee', \\ Eui-Hyug Hoang ${ }^{2}$, Jisu Kang ${ }^{3}$, Jini Lim ${ }^{4}$, Hana Lee ${ }^{5}$, Jong-Yil Chai' \\ ${ }^{1}$ Institute of Parasitic Diseases, Korea Association of Health Promotion, Seoul 07649, Korea; ${ }^{2}$ Health Examination Management Bureau, Korea \\ Association of Health Promotion, Seoul 07649, Korea; ' Daejeon-Chungnam Branch, Korea Association of Health Promotion, Daejeon 35264 , \\ Korea; ${ }^{4}$ Jeonbuk Branch, Korea Association of Health Promotion, Jeonju 54893, Korea; ${ }^{5}$ Gwangju-Jeonnam Branch, Korea Association of Health \\ Promotion, Gwangju 61931, Korea
}

\begin{abstract}
Gymnophalloides seoi (Digenea: Gymnophallidae) is a human intestinal trematode contracted by eating raw oysters (Crassostrea gigas) in the Republic of Korea (=Korea). It has been known to be highly endemic in Aphae Island, Shinan-gun, Jeollanam-do (Province). However, recent epidemiological status of G. seoi has not been reported since the 1990s. In this study, we investigated the prevalence of G. seoi metacercariae in natural and cultured oysters collected from 3 islands and 2 coastal areas in western parts of Korea. The oysters were examined using the artificial digestion method followed by stereomicroscopy. The overall positive rate of $G$. seoi metacercariae in natural oysters was $66.0 \%$ (99/150), and the oysters collected from Yubu Island showed the highest infection rate (74.0\%). However, the metacercarial density per oyster was relatively low (1.5-2.4 per oyster). By contrast, no metacercaria was found in cultured oysters purchased from 2 coastal areas in Chungcheongnam-do. Thus, we could confirm that natural oysters produced from 3 western coastal islands are infected with G. seoi metacercariae, whereas cultured oysters purchased from 2 coastal areas were free from infection.
\end{abstract}

Key words: Gymnophalloides seoi, natural oyster, cultured oyster, metacercarial survey, western coastal area, Korea

Gymnophalloides seoi Lee, Chai and Hong, 1993 (Digenea: Gymnophallidae) was discovered as a new human intestinal trematode in a female patient suffering from acute pancreatitis and gastrointestinal troubles in the Republic of Korea ( $=$ Korea) [1]. The patient resided in a coastal village of Aphae Island, Shinan-gun, where $49.0 \%$ of the villagers were positive for G. seoi eggs [2]. Natural oysters, Crassostrea gigas, were found to carry the metacercariae of G. seoi and play the role of a source of human infection [3]. A species of migrating birds, in particular, the Palearctic oystercatcher (Haematopus ostralegus), caught nearby the endemic area was confirmed to be a natural definitive host $[4,5]$.

Epidemiological investigations have reported that human G. seoi infection is widespread along the western and southern

\footnotetext{
- Received 30 September 2019, revised 21 October 2019, accepted 21 October 2019.

*Corresponding author (mulddang@gmail.com)

(c) 2019, Korean Society for Parasitology and Tropical Medicine

This is an Open Access article distributed under the terms of the Creative Commons Attribution Non-Commercial License (http://creativecommons.org/licenses/by-nc/4.0) which permits unrestricted non-commercial use, distribution, and reproduction in any medium, provided the original work is properly cited.
}

coastal areas of Korea, including islands [2,6-9]. It is also known that natural oysters produced from various localities of western and southern coastal areas are infected with the metacercariae [10-13]. However, the status of G. seoi metacercarial infection in cultured oysters has seldom been the subject of study. Only 1 recent paper [13] reported absence of G. seoi metacercariae in cultured oysters $(\mathrm{n}=1,101)$ purchased from a local market in Daejeon City. However, monitoring of G. seoi metacercarial infection in oysters is strongly needed to determine the risk of human infections with this fluke. Thus, in the present study, a small survey was undertaken to know the status of G. seoi metacercarial infection among natural as well as cultured oysters collected from several western coastal areas, including islands, of Korea.

From September 2017 to March 2018, a total of 306 oysters, which included 150 natural and 156 cultured oysters, were collected from 3 western coastal islands and 2 western coastal areas, respectively, by 3 branch offices (Daejeon Chungnam, Jeonju Jeonbuk, and Gwangju Jeonnam) of Korea Association of Health Promotion (Fig. 1; Table 1). Fifty natural oysters 
each were collected from Yubu Island (35.993347, 126.613431, Janghang-eup, Seocheon-gun, Chungcheongnam-do), Munyo Island (35.831031, 126.4383134, Okdo-myeon, Gunsan-si, Jeollabuk-do), and Aphae Island (34.844636, 126.266239, Aphae-eup, Shinan-gun, Jeollanam-do). Cultured oysters were purchased from local markets in Seobu-myeon, Hongseong-gun $(\mathrm{n}=136)$ and Iwon-myeon, Taean-gun $(\mathrm{n}=20)$ in Chungcheongnam-do.

The collected oysters were transported to the Institute of Parasitic Diseases, Korea Association of Health Promotion, Seoul,

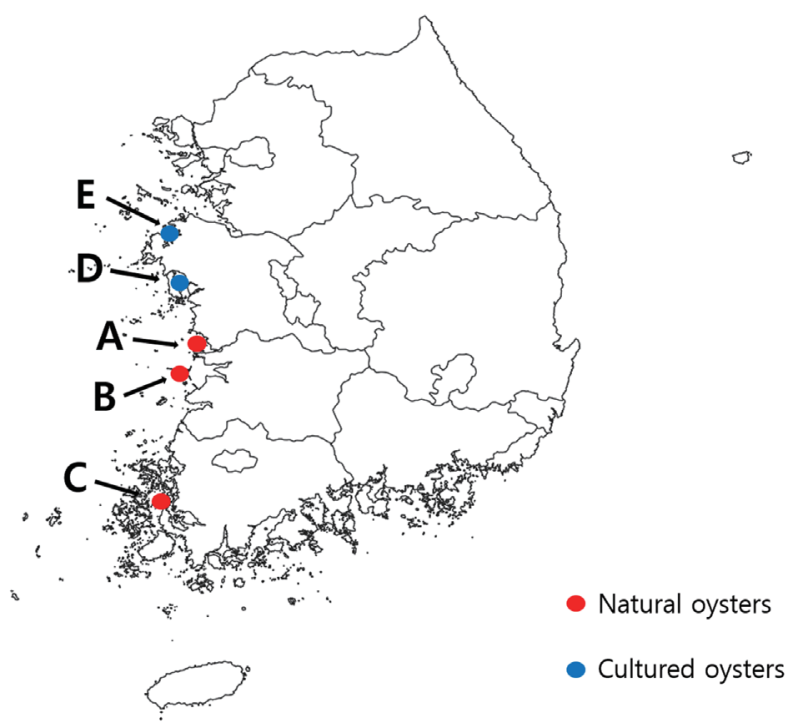

Fig. 1. Surveyed areas for natural and cultured oysters. (A) Yubu Island in Chungcheongnam-do. (B) Munyo Island in Jeollabuk-do. (C) Aphae Island in Jeollanam-do (a locality different from the known high endemic area, Shinjang 3-ri). (D) Seobu-myeon in Chungcheongnam-do. (E) Iwon-myeon in Chungcheongnam-do, Korea.
Korea. After measurements of the size and weight, the animal part of the oyster was isolated from the shell with a knife, and was digested with artificial gastric juice (pepsin- $\mathrm{HCl}$ solution) for $1 \mathrm{hr}$ in a $37^{\circ} \mathrm{C}$ incubator. The digested material was filtered through gauze, and $0.85 \%$ saline was added to the filtered solution. Washing with saline was continued until the supernatant became clear. The metacercariae were examined using a stereomicroscope (Leica KL 300 LED, Leica microsystems, Wetzlar, Germany).

The surveyed data could be summarized as shown in Table 1. Out of a total of 150 natural oysters from 3 coastal islands, 99 (66.0\%) were infected with a total of 309 metacercariae (av. 2.1 per oyster examined) (Table 1). The oysters collected from Yubu Island showed the highest prevalence (74.0\%) with the average metacercarial density of 2.4 per oyster. The oysters collected from Aphae Island revealed a similar infection rate and density in comparison with those collected from Yubu Island (Table 1). The oysters collected from Munyo Island revealed the lowest prevalence among the 3 locality groups. In contrast, all of the cultured oysters $(n=156)$ collected from 2 localities of Chungcheongnam-do revealed no metacercariae of G. seoi (Table 1).

In previous studies, it was suggested that the geographical distribution of G. seoi metacercariae might be wider than expected, and the metacercarial prevalence might be high in some localities $[7,10-12]$. However, based on the present results, the prevalence and intensity of G. seoi metacercariae seem to be decreasing in oysters from western coastal areas, including Aphae Island. In 1995, on Aphae Island, the prevalence of G. seoi metacercariae was $100 \%$, and the average metacercarial density per oyster was $610(2-4,792$ in range) [3] or

Table 1. Prevalence and density of Gymnophalloides seoi metacercariae in natural and cultured oysters from western parts of Korea

\begin{tabular}{|c|c|c|c|c|c|c|}
\hline \multirow[b]{2}{*}{ Surveyed area } & \multirow[b]{2}{*}{ Area code ${ }^{a}$} & \multirow{2}{*}{$\begin{array}{l}\text { No. of oysters } \\
\text { examined }\end{array}$} & \multirow{2}{*}{$\begin{array}{l}\text { No. of oysters } \\
\text { infected (\%) }\end{array}$} & \multicolumn{3}{|c|}{ No. of metacercariae detected } \\
\hline & & & & Total & Range & $\begin{array}{c}\text { Average no./ } \\
\text { oyster }\end{array}$ \\
\hline \multicolumn{7}{|l|}{ Natural oysters } \\
\hline Yubu Island (Seocheon-gun) & A & 50 & $37(74.0)$ & 121 & $1-9$ & 2.4 \\
\hline Munyo Island (Gunsan-si) & $\mathrm{B}$ & 50 & $27(54.0)$ & 75 & $1-13$ & 1.5 \\
\hline Aphae Island ${ }^{b}$ (Shinan-gun) & C & 50 & $35(70.0)$ & 113 & $1-16$ & 2.3 \\
\hline Subtotal & & 150 & $99(66.0)$ & 309 & $1-16$ & 2.1 \\
\hline \multicolumn{7}{|l|}{ Cultured oysters } \\
\hline Seobu-myeon (Hongseong-gun) & $\mathrm{D}$ & 136 & $0(0.0)$ & 0 & $0-0$ & 0.0 \\
\hline Iwon-myeon (Taean-gun) & $E$ & 20 & $0(0.0)$ & 0 & $0-0$ & 0.0 \\
\hline Subtotal & & 156 & $0(0.0)$ & 0 & $0-0$ & 0.0 \\
\hline
\end{tabular}

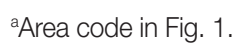

${ }^{b}$ Oysters were collected from an area different from the known highly endemic area (Shinjang-3-ri). 
even higher, 786 [10]. In the present study, the prevalence and intensity of G. seoi metacercariae in oysters from Aphae Island appeared to be decreasing. In a previous study in Aphae Island, the prevalence was $12.5 \%$ and the average intensity was 2.2 metacercariae per infected oyster [13].

It is worthwhile to mention that the prevalence and intensity of G. seoi metacercariae in oysters are highly variable even within Aphae Island $[7,9]$. Among the endemic areas of G. seoi so far reported, the most highly endemic focus with the highest metacercarial prevalence and burden in oysters and the highest infection rate of the villagers has been Shinjang-3-ri on Aphae Island [14]. However, our recent observation showed that even in the known endemic area (Shinjang-3-ri), the prevalence and intensity of $G$. seoi metacercariae in oysters are not as high as those observed before (unpublished observations). The present study, therefore, investigated the oysters collected from the western part of Aphae Island, at least $5 \mathrm{~km}$ apart from Shinjang-3-ri.

There seem to be several speculations regarding the reason for the decrease of metacercarial infection in oysters. One of the possibilities is that changes in the geographical distribution of migratory birds which act as a natural definitive host influenced the distribution of this fluke species through a change of environment on the western coast of Korea [15]. Studies have shown that up to $65 \%$ of tidal flats have been reduced during 5 decades on the western coast of Korea, and these losses could have affected the fauna of migratory birds, including the Palearctic oystercatcher, Haematopus ostralegus [15-17].

According to recent paleoparasitological reports on mummies of the Joseon Dynasty $[18,19]$, G. seoi infection may have been prevalent more widely before; the endemic locality may have been extended to Sapgyo (northern coast) and Hadong areas (eastern coast). Thus, it is suggested that the decrease in G. seoi infection in Korea have started much earlier (several hundred years ago) than we can imagine [18,19].

It is also possible to speculate that the contraction of the endemic area of G. seoi infection in Korea has been accelerated by recent environmental changes. However, more data and further studies are needed to support this suggestion.

The present study showed that all cultured oysters collected from 2 western coastal areas revealed no G. seoi metacercarial infection. A previous study also reported that all cultured oysters collected from a fish market in Daejeon City revealed no G. seoi infection [13]. It can be predicted that cultured oysters would be free from G. seoi infection, since oyster farms in Korea mainly use the hanging culture method to raise oysters [20]. Using this method, contact of oysters with eggs, miracidia, or cercariae of G. seoi might be more difficult compared with natural oysters which live under shallow sea water or attached on the rock.

Conclusively, in this study, we could confirm that a fairly high prevalence of G. seoi metacercariae is maintained among natural oysters from 3 western coastal islands of Korea, although the intensity of infection is relatively low. Meanwhile, cultured oysters collected from 2 western coastal areas were found to be free from $G$. seoi metacercarial infection.

\section{ACKNOWLEDGMENT}

This study was supported by a grant from the Ministry of Food and Drug Safety, the Republic of Korea, in 2017-2019 (17162MFDAS034).

\section{CONFLICT OF INTEREST}

We have no conflict of interest related to this work.

\section{REFERENCES}

1. Lee SH, Chai JY, Hong ST. Gymnophalloides seoi n. sp. (Digenea: Gymnophallidae), the first report of human infection by a gymnophallid. J Parasitol 1993; 79: 677-680.

2. Lee SH, Chai JY, Lee HJ, Hong ST, Yu JR, Sohn WM, Kho WG, Choi MH, Lim YJ. High prevalence of Gymnophalloides seoi infection in a village on a southwestern island of the Republic of Korea. Am J Trop Med Hyg 1994; 51: 281-285.

3. Lee SH, Choi MH, Seo M, Chai JY. Oysters, Crassostrea gigas, as the second intermediate host of Gymnophalloides seoi (Gymnophallidae). Korean J Parasitol 1995; 33: 1-7.

4. Ryang YS, Yoo JC, Lee SH, Chai JY. The Palearctic oystercatcher Haematopus ostralegus, a natural definitive host for Gymnophalloides seoi. J Parasitol 2000; 86: 418-419.

5. Ryang YS, Yoo JC, Lee SH, Chai JY. Susceptibility of avian hosts to experimental Gymnophalloides seoi infection. J Parasitol. 2001; 87: 454-456.

6. Chai JY, Lee GC, Park YK, Han ET, Seo M, Kim J, Guk SM, Shin EH, Choi MH, Lee SH. Persistent endemicity of Gymnophalloides seoi infection in a southwestern coastal village of Korea with special reference to its egg laying capacity in the human host. Korean J Parasitol. 2000; 38: 51-57.

7. Chai JY, Park JH, Han ET, Shin EH, Kim JL, Hong KS, Rim HJ, Lee SH. A nationwide survey of the prevalence of human Gym- 
nophalloides seoi infection on western and southern coastal islands in the Republic of Korea. Korean J Parasitol. 2001; 39: 2330.

8. Guk SM, Park JH, Shin EH, Kim JL, Lin A, Chai JY. Prevalence of Gymnophalloides seoi infection in coastal villages of Haenam-gun and Yeongam-gun, Republic of Korea. Korean J Parasitol 2006; 44: 1-5.

9. Park JH, Guk SM, Shin EH, Kim HJ, Kim JL, Seo M, Park YK, Chai JY. A new endemic focus of Gymnophalloides seoi infection on Aphae Island, Shinan-gun, Jeollanam-do. Korean J Parasitol 2007; 45: 39-44.

10. Lee SH, Sohn WM, Hong SJ, Huh S, Seo M, Choi MH, Chai JY. A nationwide survey of naturally produced oysters for infection with Gymnophalloides seoi metacercariae. Korean J Parasitol 1996; 34: 107-112.

11. Sohn WM, Ryang YS, Chai JY, Lee SH. Discovery of Gymnophalloides seoi metacercariae in oysters from islands of the West Sea known as the habitats of Paleartic oystercatchers. Korean J Parasitol 1998; 36: 163-169.

12. Sohn WM, Na BK, Cho SH, Lee WJ. Prevalence and density of digenetic trematode metacercariae in clams and oysters from western coastal regions of the Republic of Korea. Korean J Parasitol 2017; 55: 399-408.

13. Kim HC, Hong EJ, Ryu SY, Chae JS, Park J, Choi KS, Yu DH, Park
BK. Metacercariocidal effects and infection status of Gymnophalloides seoi in oysters. J Prev Vet Med 2019; 43: 74-77.

14. Lee SH, Chai JY. A review of Gymnophalloides seoi (Digenea: Gymnophallidae) and human infections in the Republic of Korea. Korean J Parasitol 2001; 39: 85-118.

15. Murray NJ, Clemens RS, Phinn SR, Possingham HP, Fuller RA. Tracking the rapid loss of tidal wetlands in the Yellow Sea. Front Ecol Environ 2014; 12: 267-272.

16. Lee HS, Yi JY, Kim HC, Lee SW, Paek WK. Yubu Island, the important waterbird habitat on the west coast of Korea and its conservation. Ocean Polar Res 2002; 24: 115-121.

17. Kang TH, Cho HJ, Kim IK, Lee YS, Lee SW. Avifauna at spring season in Yubudo island, Korea. J Korean Nat 2010; 3: 213-218.

18. Seo M, Shin DH, Guk SM, Oh CS, Lee EJ, Shin MH, Kim MJ, Lee SD, Kim YS, Yi YS, Spigelman M, Chai JY. Gymnophalloides seoi eggs from the stool of a 17th century female mummy found in Hadong, Republic of Korea. J Parasitol 2008; 94: 467-472.

19. Shin DH, Oh CS, Chai JY, Ji MJ, Lee HJ, Seo M. Sixteenth century Gymnophalloides seoi infection on the coast of the Korean Peninsula. J Parasitol 2012; 98: 1283-1286.

20. Choi YJ, Tri NT, Lee JM, Kang SJ, Choi BD. Evaluation of nutrients during rack and bag culture or suspended culture of Pacific oyster Crassostrea gigas. Korean J Fish Aquat Sci 2017; 50: 263269. 